\title{
The International Circulation of Elites: Knowledge, Entrepreneurial and Political
}

\section{Andrés Solimano ${ }^{1}$ and Diego Avanzini ${ }^{2}$}

October 2010

\begin{abstract}
International migration analysis often focuses on mass migration rather than on the international mobility of elites, which is the focus of this paper. The paper offers a three-fold classification of elites: (a) knowledge elites, (b) entrepreneurial elites and (c) political elites. We explore the concept of elites and their main motivation to move across nations and review indirect empirical evidence relevant to this type of mobility, highlighting some channels through which elites can affect international development.
\end{abstract}

Keywords: International migration, entrepreneurial, political migrants, talent mobility JEL classification: F22, J61, L26, O15

Copyright (C) UNU-WIDER 2010

1 Facultad Latinoamericana de Ciencias Sociales (FLACSO), Santiago, Chile, e-mail: asolimano@gmail.com 2 George Mason University, Arlington, Virginia, USA, e-mail: avanzini@gmail.com

This study has been prepared within the UNU-WIDER project on The Role of Elites in Economic Development, directed by Alice Amsden, James Robinson, and Alisa DiCaprio.

UNU-WIDER gratefully acknowledges the financial contributions to the research programme by the governments of Denmark (Royal Ministry of Foreign Affairs), Finland (Ministry for Foreign Affairs), Sweden (Swedish International Development Cooperation Agency-Sida) and the United Kingdom (Department for International Development—DFID). 


\section{Acknowledgements}

Paper prepared for the UNU-WIDER conference on The Role of Elites in Economic Development held in Helsinki on 12-13 June 2009. We are thankful to participants for their comments and encouragement. We also appreciate comments from Alice Amsden and two anonymous referees.

Tables and figures appear at the end of the paper.

The World Institute for Development Economics Research (WIDER) was established by the United Nations University (UNU) as its first research and training centre and started work in Helsinki, Finland in 1985. The Institute undertakes applied research and policy analysis on structural changes affecting the developing and transitional economies, provides a forum for the advocacy of policies leading to robust, equitable and environmentally sustainable growth, and promotes capacity strengthening and training in the field of economic and social policy making. Work is carried out by staff researchers and visiting scholars in Helsinki and through networks of collaborating scholars and institutions around the world.

www.wider.unu.edu publications@wider.unu.edu

UNU World Institute for Development Economics Research (UNU-WIDER)

Katajanokanlaituri 6 B, 00160 Helsinki, Finland

Typescript prepared by Janis Vehmaan-Kreula at UNU-WIDER

The views expressed in this publication are those of the author(s). Publication does not imply endorsement by the Institute or the United Nations University, nor by the programme/project sponsors, of any of the views expressed. 


\section{Introduction}

A largely neglected topic in the economics of development and globalization is the formation of elites and their mobility across nations. International migration is often considered in terms of skilled and unskilled people but rarely in terms of elites. Nevertheless, elites are important as carriers of knowledge, capital, contacts, ideas, creativity and leadership.

The concept of elites was developed by the 'Italian school'. Main representatives of this school were Vilfredo Pareto (1848-1923), an economist and sociologist, and the political scientist Gaetano Mosca (1858-1941). On the other side of the Atlantic, the American sociologist C. Wright-Mills, in The Power Elite expanded the concept to include the economic, political, and military 'power elite' in the USA. Pareto (1991) viewed elites as 'people with exceptional qualities', thus holding a largely meritoriented concept of elites. Pareto then envisaged history as a circulation of elites mainly within nations; his main concern was not the international circulation of elites. In the Ruling Class, Mosca indicates that the main source of power for the ruling class (elites) is their superior internal organization, enabling them to 'have a disproportionate influence over the vast majority of society despite their numerically small group'. Knowledge and organization are key elements for a group to become elite.

Elites are individuals that have a capacity to save, invest, and generate knowledge, technology and creativity well above the average of the population. They also wield economic and political power. The international mobility of economic elites generates economic value and transfer investment, technology, new products and ideas across different countries. Political elites, in turn, shape the governance of society under which economic activities take place. The concept of elites conveys the idea of a small group of people that have an impact on society and the global and national economy that goes well beyond their quantitative number. The elites we refer to in this paper include people with special knowledge in the scientific and technological fields, professionals in the private and public sector, entrepreneurs with leading roles in innovation and technology transfer and politicians and social leaders.

This paper is exploratory. It elaborates on a topic that we believe is important, how elites become transnational and why their mobility is bound to be important from the viewpoint of international development. It offers first a classification of different types of elites, distinguishing between knowledge elites, entrepreneurial elites, and political elites, examining the main features and particularities of each type of elite from the perspective of their international mobility. Then, the paper presents and discusses empirical evidence available on the mobility of people with high knowledge, creative power and entrepreneurial capabilities while discussing some suggestive evidence on mobility of politicians, still a largely unexplored field of analysis. We analyze the possible impact of each type of elites on economic development highlighting relevant channels such as knowledge generation, patents, enterprise creation, scientific knowledge, books, and works of art. We present and review several indicators that provide preliminary evidence for studying the impact of the activity of the elites, how they mobilize and concentrate across countries. The paper closes with some concluding remarks and directions for further research. 


\section{Concept and types of elites}

In this paper we concentrate on three types of elites: knowledge, entrepreneurial, and political elites. These elites are not necessarily the kind of elites associated with 'power elites' (Wright-Mills [1956] 2000) or 'special or superior' persons in the sense of Mosca (1960) 1 though the concepts are not entirely unrelated. In fact, possessing knowledge, capital or political contacts give those who own these resources or attributes, 'power' The knowledge and entrepreneurial elites we are considering include professionals, scientists, medical doctors, graduate students, cultural workers and entrepreneurs. We consider also political elites in this paper, highlighting their different nature from knowledge-based and entrepreneurial elites.

Although these elites may overlap with each other, the economics and sociology implied in the formation and patterns of mobility, both nationally and internationally, are different; these complex processes deserve attention and study. Their differences cover a broad range of distinctive dimensions such as the way they join foreign labour markets, as well as salary levels, career paths, promotion criteria, and so forth. In the case of entrepreneurs their access to product markets, capital markets and other services markets is relevant.

\subsection{Knowledge elites}

A main asset in today's world is knowledge. People that generate, disseminate and apply knowledge have a special advantage. When we talk about knowledge elites we assume the main linking force among these individuals is the high talent and knowledge that these people carry with them. These elites involve a range of individuals: those who generate scientific knowledge, people who apply scientific and technological knowledge to production, innovation, business, academia, and people engaged in valuable social and cultural activities. Globalization enables the spread, across countries, of new information technologies, new products, services, and ideas. The occupations of knowledge elites include independent professionals and experts, academics, scientists and scholars in university and research centers, executives and managers working in multinational corporations and professional staff of public international organizations. The international dimension of knowledge elites relates to the spreading of ideas, knowledge, and technology across countries. The development of knowledge elites takes place both in source countries through education at home and abroad (international students, professionals and through international exchange), and in the receiving countries that support the education and development of foreign talented people and collaborate with origin countries to repatriate them. The circulation of talent helps to mobilize knowledge, ideas, and technological innovation and directly impacts economic activity in source and receiving nations.

\section{Roles and impact of knowledge elites}

Solimano (2008) distinguishes four types of 'talent' that are internationally mobile. These types of talent are closely related to knowledge elites:

1 Also Pareto ([1968] 1991) pointed out that elites comprise 'people with exceptional qualities,' or those considered almost 'superior members of society'. 
1. Directly productive technical and managerial talent: this category includes people in positions in the production process such as executives, managers, and technical engineers who are important engines of production processes. Their productive contributions range from overseeing production, managing people, changing organizational structures and strategies, developing new business lines, machinery enhancement, etc. Their contribution towards development and economic growth can be measured by changes in market shares of their respective companies, changes in labour- or capital-intensity in productive processes, and by the outcomes of the managerial models they are applying.

2. Scientific talent: this group - comprising academics, scientists, international students, and researchers - helps to create and spread knowledge and their contributions take place primarily in universities and research centers. Perhaps this is the most studied group and its mobility has been analyzed for many years starting with the concept of 'brain drain', and gradually changing to 'brain circulation'.

3. Health talent: this is a wide group of people consisting of physicians, surgeons, dentists, therapists, and mental health professionals. It also includes nurses, pharmacists, clinical scientists, and paramedics. The consequences of its international mobility may be detrimental for the health sector of the origin country, mainly when health professionals come from low to middle income nations. Part of the health mobility, however, has gained scene worldwide thanks to altruistic or international programmes such as World Health Organization, International Committee of the Red Cross, Médecins Sans Frontières - Doctors without Borders, Project HOPE, Oxfam International, and many others.

4. Cultural and social talent: includes artists, musicians, writers, media-related people, free-thinkers, social entrepreneurs, and other social-change promoters, 2 who help to spread cultural products and social values around the world.

These four categories may have different motivations for moving internationally. Managers and technical people tend to move within-companies (intra-firm employee transfers) or across companies in different countries. International wage differentials and compensation schemes are important drivers of executives' mobility. Scientists are more interested in moving to countries that offer larger budgets for doing research, more possibilities to publish and higher salaries. Health sector professionals react to professional and ethical challenges, wage differentials and career possibilities and cultural talent also look at the possibilities for greater recognition and interaction with peers abroad.

2 As an example of social entrepreneurs and well-being promoters we recall Dr Muhammad Yunus, the banker and economist from Bangladesh, founder of the Grameen Bank and developer of the concept of micro-credit. He was awarded the Nobel Peace Prize 2006 due to 'efforts to create economic and social development from below. Lasting peace cannot be achieved unless large population groups find ways in which to break out of poverty. Micro-credit is one such means. Development from below also serves to advance democracy and human rights.' (The Norwegian Nobel Committee, Oslo, 13 October 2006). 


\section{$2.2 \quad$ Entrepreneurial elites}

Entrepreneurial elites are people with special skills in wealth creation, resource mobilization and innovation. Entrepreneurs are not necessarily endowed with formal university education and this feature differentiates them from the knowledge elites. The role of the entrepreneur is the organization of production and the surge of innovation. They are critical agents of the growth and development process. They engage in the development of new businesses and organizations and, most of the time, carry with them a flow of capital and new technologies. Still the distinction between the knowledge and entrepreneurial elites is not as sharp: for example managers and technicians contribute critically to business creation which is the role of the entrepreneurial elites. In that sense there are complementarities between knowledge and entrepreneurial elites.

Although the idea of entrepreneurship is an ancient one, defining and limiting its scope is still complex. In economic theory, entrepreneurs have the distinctive feature of taking risks - a point emphasized by Frank Knight and Joseph Schumpeter - and show a talent for combining the capital and labour necessary to realize a vision of opportunity and prospective profits. In the Schumpeterian tradition, entrepreneurs are agents for mobilizing resources and investment and promoting innovation. In addition, the 'psychology' of the entrepreneur certainly differs from that of the scientist, the expert, or the intellectual with whom we usually associate the term 'human capital' and here we ascribe them to knowledge elites. In contrast, professionals, scientists, and engineers are often employees rather than owners and are supposed to be more risk-averse than entrepreneurs (Solimano 2010).

The emphasis on the role of entrepreneurship in the literature of growth economics in recent years has been generalized and the term is applied to a wide variety of phenomena. ${ }^{3}$ Here we adopt an empirical definition of entrepreneurship developed by Ahmad and Seymour (2008), that unifies various aspects and evolution of the idea of entrepreneurship (Avanzini 2008). For these authors the entrepreneur is an economic agent who 'is simultaneously looking back to the resources (and combining them in new and creative ways) and forward to markets (and perceiving new or unmet opportunities). The entrepreneur creates value by recognizing the fit between the two. The entrepreneur's activities occur within a business context, which includes industry structures, competition, and national economic structures. This business context is impacted in turn by wider environmental considerations, which include the economic, political, legal, social, cultural, and natural settings.

Using this definition entrepreneurs are naturally talented people, in a way that is not necessarily derived from formal education, but rather they possess a business vision that lets them take advantage of the rising opportunities dealing with existent resources or generating new ones. It is also clear that this type of entrepreneurship is an economic one or for profit. Another category is that of social entrepreneurs (included before within merited and talented elites) whose motivations may be altruistic and tied to social commitment; of course the actions and influences of social entrepreneurs also have an economic and social impact.

3 Some authors, such as Gartner (2001), pose the necessity for establishing unified criteria about the meaning and extent of entrepreneurship. 
Entrepreneurs - with or without formal higher education - who engage in new businesses, produce knowledge, are innovative, and move around the world to develop their ideas constitute the mobile entrepreneurial elite. For developing countries, the arrival of these entrepreneurs implies a change in established paradigms: they introduce new technologies, knowledge, and change market perspectives; sometimes they bring capital with them to develop activities contributing to generate wealth, employment, and enhance productivity.

\section{Opportunity seeking and capital mobilization by entrepreneurial elites}

The literature of entrepreneurship developed in the last 30 years or so has introduced the following distinction:

- Entrepreneurs of opportunity. This is based on the notion of 'opportunity seeking' individuals 4 who perceive business opportunities and have the capacity to mobilize resources (credit, people, technology) for seizing those opportunities. These cases are usually identified as 'opportunity entrepreneurship'.

- Entrepreneurs of necessity. In this case individuals get involved in entrepreneurial activities due to the lack of alternative economic opportunities. Generally, they are people who are currently unemployed, or their last job was not satisfactory, so they engage in new enterprise creation to generate income and meet their needs. This entrepreneurial activity is sometimes called 'necessity entrepreneurship'.5 This is typically the case of shop-owners, small workshops, micro-enterprises and so on.

In fact, we can characterize entrepreneurial activity by (i) the nature of the entrepreneurial opportunities, 6 (ii) the entrepreneurial characteristics of the individuals, 7 and (iii) the distinctive features of the decision-making environment 8 in which the entrepreneurial phenomenon takes place. The three characteristics endow entrepreneurship with particular features that also determine its economic impact, duration, and likelihood of international mobility. Despite the differences involved in the previous classification, entrepreneurship may smoothly range from opportunity to necessity, and both motivations are present to a certain degree in different types of entrepreneurs (Avanzini 2007). Internationally mobile entrepreneurs appear to be more 'opportunistic' in the sense of their search for new business opportunities and the capacity to gather resources for seizing those opportunities. These internationally

4 See Gaglio and Katz (2001), and Baron (2004).

5 See McClelland (1961), Collins and Moore (1964), and Busenitz and Barney (1997).

6 See Kirzner (1979), Shane and Venkataraman (2000), Gaglio and Katz (2001), among others.

7 This feature is studied by McClelland (1961) Collins and Moore (1964), Busenitz and Barney (1997), to name a few.

8 This characteristic has been introduced more recently in the entrepreneurship theory by Knight (2001), Alvarez and Barney (2005), among others. 
mobile entrepreneurs may be of a different size 9 and operate in various sectors. The emergence of 'technological entrepreneurs' that connect markets in different countries and regions such as say Silicon Valley in the USA with Bangalore in India or with Israel is a case at hand.

Figure 1 depicts the relationship between entrepreneurship and levels of economic development (a sort of inverted Kuznets curve for entrepreneurship). It shows the relationship between the Total Entrepreneurship Activity rate (TEA), collected by the Global Entrepreneurship Monitor (GEM 2006) and the level GDP per capita (PPP adjusted) as a proxy of development levels. The U-shaped form of this relationship has been explained by both types of entrepreneurship: while high-income countries, such as USA, Japan and EU countries show a positive relationship between entrepreneurial activity and income level (reddish-shaded area), low- and middle-income countries present a negative relationship between the two variables (light blue-shaded area). The positive slope can be interpreted as showing the relevance of opportunity entrepreneurship which is more frequent at higher per capita income levels and associated with the development of new markets, products, and the exploration of new economic activities that often imply important capital mobilization to support investment. On the other hand, the portion of the curve with a negative slope would correspond to necessity entrepreneurship, in low and middle income countries involving underemployed and unemployed people trying to meet their daily needs through small scale entrepreneurial activities. This entrepreneurship is often associated with lower capital requirements and tends to be more volatile, with a high rate of entrepreneurial exit. Some empirical evidence shows that new businesses started in countries in the light blue-shaded area - e.g. Argentina, Brazil, China, India, Peru, and Thailand, among others - are more likely to exit market activity before the 42 months. 10

This figure suggests the international mobility of entrepreneurs is related to the desire of entrepreneurs to find, in other nations, wider markets, more access to funding and technology and lower costs of doing business. This directly influences the international location of entrepreneurial activity. Thus, it seems plausible that, opportunity entrepreneurs constitute a group with a higher probability to move internationally. Some examples arise from the super-rich (Forbes' ranked billionaires). For example, the Walton family of the Wal-Mart markets chain, the Benetton family with the design and production of clothes, the MacMillan family in the agricultural field (Cargill), John de Mol and Joop van den Ende with their entertainment business, among many others. Most of them are engaged in the development of new businesses around the world in an international scale, mobilizing capital and human resources (something that affects also talent mobility) in order to exploit market opportunities in receiving countries.

Technology entrepreneurs engaged in start-ups eventually reach the stage of internationalization of their business, a critical step for the international mobility of entrepreneurs. Very often, these entrepreneurs maintain connections with their home countries and become a vehicle of development in their home countries if they bring

9 Here, 'size' refers to economic size, in the sense of the entrepreneurs' capacity to mobilize capital stocks.

10 Time limit to consider a new business as an established one, as defined in GEM (2006). 
capital, technologies and forge business connections with external markets. 11 The literature on international mobility of entrepreneurs highlights a key distinctive feature of these elite: their capacity to mobilize capital and technology across national borders, channeling capital obtained in the receiving country to support their entrepreneurial business in home countries or in other nations. 12

On the other hand, necessity entrepreneurs who responsed to economic stress, recessions and slumps, 13 are less likely to move abroad as they have fewer international connections and lower economic resources to finance mobility that is costly (transport costs, cost of job search, or business opportunity search). Still the issue needs further research as hardship and necessity is often a motivation of international migration of people.

There is a degree of international mobility of small size (necessity) entrepreneurs provided by immigrants that open small businesses in the host countries; this is typically the case of ethnic stores, cultural goods, and remittances shops, carpets stores that are owned and run by foreigners.

\subsection{Political elites}

A third category is the political elite. These elites include party leaders, congressman, heads of state, presidents and leaders of social movements with ties to political parties. These political and social leaders often have broad social network connections with their power based in their home countries.14 Up to a certain point, this is related to the concept of the 'power elite' (Wright-Mills [1956] 2000 and Mosca 1960). Political elites largely impact governance through enabling (or failing to enable) the achievement of political consensus. They shape the political environment and institutions of society, which are critical elements of stability and respect for property rights that affect investment and innovation. On the other hand, failed political elites who are unable to produce an acceptable degree of political stability and social peace or that generate an excessive level of rent-seeking and corruption may delay economic development.

11 Recent research has emphasized the role of these returning and circulating talented-entrepreneurial elites as an engine of economic growth and attractor of foreign investment. Saxenian (2006a) studies the effects of these elites in Taiwan and Israel. Saxenian (2006b and 2008) studies the effect of the adoption of the Silicon Valley model in China and India, on a case-by-case basis. On a more aggregated basis, Docquier and Lodigiani (2008) study the impact of skilled migration and their networks outside sending countries on foreign direct investment inflows in sending countries, finding important positive network externalities, namely that having a large educated diaspora abroad stimulates physical capital accumulation.

12 New businesses boosted by arriving entrepreneurs may destroy weak economic sectors or absorb incipient local entrepreneurs, exploiting scale economies, or dominating markets due to capital availability. Also entrepreneurs may generate economic instability because of their quick entry/exit behaviour (generally associated with the so-called 'flying' capital).

13 They try to overcome the difficult times with small businesses (rarely developing grand new strategies and products or big projects) and tend to disappear as soon as they get a stable job in the labour market.

14 Modern bureaucratic society values these organizational skills and rewards them with political power. Political elites use several mechanisms to support and improve their net, such, as social connections, marriage, and ownership of productive assets, ideas and beliefs, political clientelism, 'favour' exchange, etc. 
A question related to the main theme of this paper is the extent to which political elites are internationally mobile. Empirical evidence is scant on this issue, the conventional wisdom is that political elites are country-specific and do not have special traits that make them internationally mobile. Political leaders are often viewed as tied to political circumstances and social conditions of their home country. However, we also can observe groups of people that belong to transnational political networks (i.e. the international social democrat, the international Christian democrat, conservative internationals and so on). In other words, the internationalization of politics is related to the fact that certain ideologies such as liberalism, communism, social-democracy, and others that inspire social movements and political parties are international. The party leadership that manages these connections could be considered to be part of international political elite. Another source of international mobility of politicians is related to violent political change such as civil wars, coup de etats that force exile and emigration of the political leadership associated with defeated factions.

\section{Empirical evidence}

One of the weaknesses of the study of the international mobility of elites is the lack of information about their characteristics, patterns of behaviour, and their development impact. In this section we present preliminary empirical evidence that provides clues about the impact and features of elite mobility that we hope can be useful in further research on this emerging topic.

\subsection{The geographical concentration of knowledge elites in rich countries}

Measuring the concentration of elites in certain locations and countries is important to gauge the extent to which the mobility of elites reduce or widen development gaps across nations and make international development a more uneven process. The evidence suggests that talent and knowledge are often concentrated geographically in rich nations. Solimano (2010) looks at various indicators of talent such as the country distribution of Nobel Prizes in Sciences and Economics and other categories of Nobel Prizes during recent decades, and concludes that these Nobel Prizes are concentrated in high income countries in the North, with a dominating concentration in the USA: almost 63 per cent of the Nobel Prizes considered have been awarded to researchers and scientists who did their work in the USA, of which 23 per cent correspond to foreign born individuals that obtained the prize for their contributions during their stay in the USA. The UK and Germany hold 8.26 per cent of the Nobel prizes; and the others are almost equally distributed between other developing countries. See Table 1 for details on the geographical distribution of Nobel Prizes awarded to scientific and medical talent.

In the cultural field, artists, writers and painters benefit from interaction with peers and seek a milieu supportive of their creativity. In the first decades of the twentieth century important foreign painters (Picasso, Matta, Modigliani and others) and writers (Hemmingway, Stein, and Fitzgerald) concentrated in Paris. More recently García Márquez, Isabel Allende and others found support for their literary and artistic careers largely outside their home countries. In Table 2, we illustrate the distribution of the Nobel Prize in Literature for the period 1980-2008. These are uniformly awarded across countries in contrast to the prizes in science and economics that are strongly biased 
towards advanced economies. Some of the Nobel laureates of literature were awarded due to their capacity to express - in highly creative ways - the particular situations in their home countries.

There have been other attempts to describe the mobility of talent such as Florida's (2005) 'Global Creativity Index', which uses creativity as a proxy for talent. The Global Creativity Index ranges between 0 and 1 , and is a weighted average of other three indexes: talent, technology, and tolerance. Table 3 presents the values of the index and shows that the potential for creativity in high-income countries is higher than in middle income and low income countries. In rich countries there are more resources for creativity, since there is a greater critical mass of peers, and living and working environments tend to be more supportive of creative people. In this sense, the flow of talented people to developed countries and their concentration in certain geographical locations is supported by the evidence about the spillovers. At the same time, they form clusters of knowledge development linked by common interests despite their origins.

Another attempt to quantify a talent index is that of Heidrick and Struggles (2007) and the Economist Intelligence Unit (2007), presented in Table 4. This index identifies concentration of talent in certain countries (or regions) and infers patterns of international mobility. The Global Talent Index uses quantitative and qualitative data to measure the economic indicators, cultural contexts, trends in education, foreign direct investment, mortality, health and market flexibility that will impact the ability of talent to thrive in a set of 30 countries included in their study. Developed countries have the highest scores while less developed countries score lower. The level of per capita income is a key explanation variable for the concentration of talented people and knowledge elites in rich countries. In contrast, political instability and the absence of democracy tend to motivate emigration of the knowledge elites from unstable countries. As before, stable, prosperous and rich countries tend to be more attractive as places of destination for knowledge elites.

There are several reasons for explaining the concentration of scientific and health elites in high income countries. Besides higher pay and better working conditions - certainly very important factors - there are the synergies emerging from the concentration itself: the gains from interaction with colleagues in a suitable environment helps to foster intellectual production. The high level of intellectual production in high income countries is reflected in the number of scientific publications that we collect in Table 5 for the period 1998-2003. As can be expected, top-rated countries coincide with those with a greater number of awarded Nobel Prizes, giving us a hint about the importance of the interaction between talented people, and how attractive a country may be for circulating knowledge elites.

The relative abundance of talented people in the North (high-income OECD countries), serves to attract even more talent to those nations. Synergy and better economic conditions, combined with a culture that recognizes and rewards talent and historical ties with source countries, are important factors that foreign students value in choosing a country to pursue their higher-education. Vincent-Lancrin (2008) studied this group of mobile talented elites as part of the World Migration Report 2008 prepared by the OECD, and found that there exists a general trend for educated elites to move from Southern to Northern countries, and the choice of country of destination is heavily influenced by the factors listed above including the existing concentration of talent (a stock) that acts as a magnet for immigrant talent (a flow). Table 6 shows the flows of 
international students from different regions to OECD countries. In this context, we can see that, for example, historical links between Africa and Europe make the latter the preferred destiny of African students going abroad. Commercial links between North America and Asia turns the former in the destiny of choice for Asian students. Political and commercial ties direct South American students flow to North America. Geographical proximity and commercial links strengthen the connections between Oceania and Asia-Pacific.

Scientists, researchers, and health professionals tend to collaborate and produce knowledge across universities. According to Jones et al. (2008), the tendency to produce knowledge through team-work increasingly crosses disciplinary boundaries, not only in science but also in engineering and the social sciences. Multi-university research teams are the fastest growing type of authorship structure during the last three decades. In this context, elite universities, generally located in developed countries, play a dominant role in a new trend, given that research papers produce their highest-impact when they include a top-tier university. Elite universities are more interdependent, with a higherimpact and increasingly visible role in science, engineering and social sciences. The differential role and impact of elite and non-elite universities is widening. These authors conclude that despite the rising frequency of research that crosses university boundaries, the intensification of social stratification (by in-group university rank) in multiuniversity collaborations suggests a concentration of the production of scientific knowledge in fewer centers of high-impact science.

These results also extend to technical and directly productive knowledge generation, as pointed out by Wuchty et al. (2007). The authors find a similar tendency among technically talented people who collaborate in the production of directly productive inventions. In Table 7 we present some statistics on the distribution of patents registered by residents and non-residents for selected countries for the period 1998-2004. High income countries dominate the ranking, with Japan and the USA accounting for 57 per cent of patents registered around the world. However, notice the differential basis of patent registration: Japan, Germany, the Russian Federation, and France have a predominant registration of patents by residents, associated with home country production of knowledge, while countries such as Canada, China, and Australia have an increasing sharing of non-resident patent registration, indicating that those countries are more likely to be the receivers and adopters of new technologies.

We also get an idea of the extent of mobility and concentration of executive and managerial talent by looking at intra-company transferees across borders. Table 8 uses data from the OECD's World Migration Report 2008 to show evidence of this. According to the table, Argentina, Brazil, Colombia, and Venezuela have been important contributors of executives, managers, and specialized professionals working at transnational enterprises for the USA. In this context, Chile has gained relevance in the share of highly qualified employees being moved outward. This is another example of talent circulation that is rarely accounted for in usual statistics (which often only include students and academics). Many companies move their people from their offices in peripheral countries to their headquarters in USA, Japan, Germany, France, or the UK, 'draining' local managerial and technical talent, attracting them with job promotions and better economic conditions and also better education opportunities for their children (executive packages for executives that move abroad often include benefits for children to pursue studies in the receiving country). 
Also the availability of a suitable and stable economic and political environment, together with enough funding and infrastructure increase a country's attractiveness for knowledge and entrepreneurial elites who need to support their work. A usual measure of funding available for knowledge creation and application is the level of research and development expenditure, as shown in Table 9. OECD countries plus Israel more than double in average the R\&D expenditure in less developed countries. However, the implications of this empirical fact are more worrying: recently, Grossmann and Stadelmann (2008) developed a model of the impact of the mobility of high-skilled people on R\&D and infrastructure investment. They found that when emigration of talented people increases (brain drain), public spending in R\&D and infrastructure investment in sending nations is reduced. Receiving economies, on the other hand, tend to increase its investment in $\mathrm{R} \& \mathrm{D}$ and infrastructure with the immigration of talent.

For many years there has been a persistent belief that emigration of highly-skilled people damages developing countries and favours developed countries (brain drain from the global south to the north). The general picture can be seen in Figure 2: Latin America and Africa have been a source of talent that has been migrating to OECD countries. Major destinations for talent coming from developing countries during the last quarter of twentieth century have been Canada, the USA, the UK, Australia, France, and Germany. Also Figure 3 shows a similar situation in the case of health professionals, indicating that during the 14 years represented in the chart, Africa, South Asia, the Middle-East and Latin America have been exporting health talent to the North.

Receiving countries in the OECD have gradually introduced selective immigration policies designed to facilitate the entrance of highly-qualified people while the immigration of less qualified individuals is more difficult. According to the ILO (2006), many developed countries seem to be competing to attract global talent in order to strengthen their international position in the 'global war on talent'. On the supply-side, instability in origin countries, poor opportunities for intellectual development, global tendencies to agglomerate capital and human resources where they are abundant, and positive self-selection among international migrants, have also contributed to direct flows to northern countries in detriment of less developed countries in the south.

\subsection{Circulation of entrepreneurial elites}

During recent years, researchers have realized that 'brain drain', contrary to generalized beliefs, might also generate some positive spillover for sending countries. This introduced a more nuanced view to the brain drain phenomenon. Beine et al. (2008) emphasize the effect of high-skilled migration on gross human capital formation, showing that this brain drain may be beneficial in some situations. According to their findings, high-skilled migration prospects can raise the expected return to human capital and foster higher investment in education in sending countries. 15

15 They derive two main conclusions: 'First, brain drain migration contributes to an increase in the number of skilled workers living in the developing countries. This suggests that the traditionally pessimistic view of the brain drain has no empirical justification at an aggregate level. Second, the brain drain has important distributional effects among developing countries, [...]' (Beine et al. 2008: 648 , italics as in the original). Their findings are supported by the empirical fact that countries combining relatively low levels of human capital and low skilled emigration rates are more likely to experience a beneficial brain drain, i.e. a net positive effect, and conversely. This phenomenon also produces the distributional outcome these authors refer to: small countries such as those in subSaharan Africa and Central America are less able to take advantage of the brain drain so they are net 
Saxenian (2006a, 2006b, 2007), uses case studies of Israel, Taiwan, India, and China, to argue that the circulation of entrepreneurial and technological elites has beneficial impacts on sending countries. She shows that people, who have developed their careers abroad, may constitute an important source of growth in their respective home countries. This is because they return home, or use new technological devices and lower transport costs permit collaboration in real time, even on complex tasks, with counterparts located at great distances. Also the migration of talented students to developed countries to continue their high education may be viewed as something prejudicial for sending countries if they stay abroad afterwards, but new evidence shows that those emigrants are returning to their home countries, carrying with them knowledge, technology, and capital.

In Taiwan and Israel, Saxenian (2006a) focuses on the dissemination of the Silicon Valley model. According to her findings, the spread of venture capital financing has helped returning immigrants - those that once were young students 'drained' out of their home countries - to transfer the Silicon Valley model of early-stage high-risk investing to Taiwan and Israel, locations that USA venture capitalists typically had neither interest in nor ability to serve. Native-born investors promoted this capital arrival providing the cultural and linguistic know-how needed to operate in these markets, bringing technical and operating experience, knowledge of new business models, and networks of contacts in the USA. She highlights the fact that when foreigneducated venture capitalists invest in their home countries they transfer first-hand knowledge of the financial institutions of the new economy to peripheral regions.

However, this reverse-migration process does not work everywhere in the same way. Saxenian argues that although developing countries that invested heavily in education in the postwar period also suffered the most from 'brain drain', when their most successful students left home to take advantage of educational and economic opportunities in wealthier and more advanced economies - not all countries are prepared to take advantage of the benefits of reversed migration and entrepreneurial elites action. Some developing economies in Africa and Latin America have failed to invest in higher education (particularly technical education) and have no suitable labour force to engage domestic economies in such entrepreneurial activity. Others - e.g. Iran and the Russian Federation - have been too politically unstable to attract large numbers of technically skilled returnees. Still others, like Singapore and Scotland, have sufficient skill but have oriented domestic institutions - including capital markets, regulatory, educational and research institutions, labour markets, and so forth - toward attracting foreign investment rather than supporting indigenous entrepreneurship. In many Asian countries, government support for large scale, capital intensive investments in the 1970s and 1980s, either by domestic corporations (Korea) or by multinationals (Singapore), had created relatively inhospitable environments for entrepreneurial experimentation.

Recently, a new measure of entrepreneurship - developed in Avanzini (2009) - supports these conclusions offering key empirical information to understand the changing attractiveness of countries for entrepreneurs. In this context, entrepreneurship is measured by means of a composite indicator that includes seven aspects of

losers in this context, while big developing countries such as China, India, and Brazil seem to obtain non-negligible gains due to the brain drain. 
entrepreneurial activity, its environment and impact, namely entrepreneurial activity (including firm dynamics, firm survival, and ownership); entrepreneurship spirit, culture, and initiative; barriers to entrepreneurial activity and business environment; knowledge procurement; innovation; impact on employment; and impact on economic activity. The attractiveness of a country is measured by the relevant aspects it may offer to entrepreneurs, and these aspects evolve through time changing entrepreneurs' location decisions in order to take advantage of the opportunities. Table 10 shows the relevance of each aspect for two periods, 1998-2001 and 2002-2005, and the rank of a set of selected countries.

Some countries, such as the USA, Japan, Republic of Korea, and Switzerland have traditionally been considered suitable places for hosting entrepreneurial activities. However, other countries like Israel, China, Brazil, Mexico, and India, have made major efforts in recent years to make themselves more attractive to entrepreneurs. The fostering and quality improvement of higher-education (particularly, technical education), and the investment in infrastructure, technology, and telecommunications, helped to shape a more comfortable environment to install new enterprises, much of them being outsourcers of big transnational companies. Also some changes to the law and bureaucratic procedures have reduced administrative barriers to entry and diminishing cost of doing business, both being relevant factors to encourage new productive activities. Other developing countries such as Argentina and the Russian Federation are making efforts to become more attractive to international mobile investors though economic and political instability in these countries threaten their possibilities. 16

\subsection{International mobility of political elites}

For many years, the general belief has been that political elite are less mobile than others due to the fact that their constituencies are home-based and provide the support to maintain their power basis at home. However, there is some evidence that point to a degree of international mobility of the political elite. We can identify the following channels for this mobility: (a) individuals who later became national leaders in their home countries originally had left their home countries to follow their higher-education in foreign universities (b) part of the political class becomes mobile across national boundaries by assuming posts of international representation and diplomacy (c) political leaders that are members of international networks (social-democrats, liberals, socialists, communists) move internationally as part of their political work (d) violent political change such as coups de etat, civil war, internal conflict, a turn to authoritarian politics in the home-countries force or compel political leaders to move to other nations.

The empirical evidence around these four categories is still scant. A piece of evidence on political leaders who have studied abroad earlier and come into prominence in their home country (our channel a) is provided by Spilimbergo (2007, Table 10). According

16 As pointed out by Saxenian (2007), today’s returning entrepreneurs have accelerated the adaptation of technology and institutions to local circumstances, transferring production to a new environment, contributing with their knowledge of the local context, and bridging the differences in social, cultural, and institutional settings. Production division and specialization, reduction in the cost of transportation, and the rapid improvement of communication allow these highly mobile entrepreneurs to build and maintain long distance partnerships to tap overseas expertise, cost savings, and markets. 
to his findings, more than half of the political leaders who had relevant positions in their countries of origin in the 1990s chose to study abroad, and the preferred destinies were the USA, the UK, France, and Russia. As explained by Spilimbergo, and in connection with the previous discussion on student mobility, the existence of former political and historical connections between countries of origin and destination (e.g. colonies) helped to explain those choices by international students. Political leaders also tend to move to places where exists previous political, cultural, idiosyncratic, and historical links between the sending and the destination country. 17

Historical examples related to our channel (d) would be the exile of the government of the Spanish Republic, led by Manuel Azaña, after the Republicans lost the civil war in 1939; the self-exile and hiding of many Nazi leaders after the end of the Second World War (several of them ended up in Argentina, Chile and Paraguay); the exile of Guatemala's President Jacobo Arbenz in 1956 after a USA-led coup d'état; the exile in Spain of Argentinean leader Juan Domingo Peron in 1955 until his return to Argentina in early 1973 and several other examples.

\section{Concluding remarks}

This paper is exploratory and deals with a largely under-researched topic: the international mobility of elites. The topic is complex on many levels starting by the very definition of elites, and the nature of their development effects. The literature has highlighted the issue of brain drain but nowadays we face more complex patterns of brain and talent circulation that suggest that sending countries may also benefit from the international mobility of knowledge and entrepreneurial elites. In addition, political elites are, to some extent, also internationally mobile although for different reasons than those guiding the mobility of economic elites.

A suggestive classification we adopt in this paper is that of knowledge, entrepreneurial and political elites. Knowledge elites are heterogeneous and composed by high level managers and executives, scientists and academics, people in the health sector and cultural activities. In general their main comparative edge lies in the possession of specific knowledge and talent that is privately and socially useful for scientific, technological and commercial purposes. Globalization and the increased interconnection among countries greatly increase the economic value of this talent and its international mobility. The international mobility of entrepreneurs is somewhat different. Entrepreneurs move across national boundaries because of more attractive business opportunities, less red tape and bureaucracy, more credit to fund business and larger markets are found in other countries than at home. In the paper we use the distinction between entrepreneurs by opportunity and entrepreneurs by necessity with the former being probably more internationally mobile than the latter. Still in many recipient countries there is also a flourishing segment of foreign small size entrepreneurs in the services sectors such as restaurants, commerce and others. Return migration and circulation of technological entrepreneurs is a new feature that connects economies and regions in ways not considered years ago.

17 In this context, it is not strange that people coming from Eastern Europe during the social period chose the Soviet Union as a place to study. In turn, students from former colonies in Africa prefer UK and France to follow their education. 
The empirical evidence reviewed in this paper shows a high concentration of professionals, scientists and innovators in high income countries reinforcing development gaps in the global economy as valuable human capital move from low and middle income countries to rich nations. However, new patterns of mobility of talent, capital and technology have emerged in which sending countries may also benefit (the typical case of technological entrepreneurs that emigrated from India, Taiwan, Israel to the USA or Europe and play a connecting role transferring technologies, know-how and market contacts to emerging economies).

The international mobility of politicians which is little investigated in the literature, is a new topic that we consider in this paper. We identify the forced mobility of politicians and social leaders after losing their positions following violent political change in their home countries. In these cases, political leaders may choose to live abroad, often in exile. We also find some empirical evidence showing that political leaders in developing countries often obtain education in universities in Europe and North America in their youth, and this education proves to be a source of international contacts useful for their future political careers at home. In addition, some degree of intra-developing countries mobility in the educational field exists for future politicians and civil servants.

Topics for future research emerging from this paper include a better understanding of the determinants of entrepreneurial migration by size, motivation and degree of technological sophistication. Also we need to know more about the patterns of international talent mobility within the private sector (i.e. multinational corporations) compared with the mobility of independent professionals and entrepreneurs. Also more research is needed on the patterns of international mobility of people within the international public sector including both the technocracy of international organizations and political representatives in those organizations. More research is needed for understanding the international mobility of social leaders and politicians, too. Research in all these topics would benefit from joint work and professional dialogue between economists, sociologists and political scientists. Moreover, better and more statistical data and qualitative analysis would certainly help in advance our understanding of the determinants of the international mobility of elites. 


\section{References}

Ahmad, N., and R. G. Seymour (2008). 'Defining Entrepreneurial Activity: Definitions Supporting Frameworks for Data Collection’. OECD Statistics Directorate, Working Paper STD/DOC (2008) 1, January.

Alvarez, S. A., and J. B. Barney (2005). 'How do Entrepreneurs Organize under Conditions of Uncertainty?’. Journal of Management, 31 (5): 776-93.

Avanzini, D. B. (2007). 'Emprendimiento y Crecimiento Económico: Resultados Para una Muestra de 42 Países’. Unpublished manuscript, Catholic University of Chile.

Avanzini, D. B. (2008). 'Composite Entrepreneurship Indicators: Theoretical Derivation and General Methodology’. Unpublished manuscript, Catholic University of Chile.

Avanzini, D. B. (2009). 'Designing Composite Entrepreneurship Indicators: An Application using Consensus PCA', UNU-WIDER Research Paper No. 2009/41. Forthcoming in UNU-WIDER (ed.), Entrepreneurship and Economic Development: Theory, Measurement and Policy, Ch. 7.

Baron, R. A. (2004). 'The Cognitive Perspective: A Valuable Tool for Answering Entrepreneurship’s Basic “Why” Questions'. Journal of Business Venturing, 19 (1): 221-39.

Beine, M., F. Docquier, and H. Rapoport (2008). 'Brain Drain and Human Capital Formation in Developing Countries: Winners and Losers'. The Economic Journal, 118 (528): 631-52.

Busenitz, L., and J. B. Barney (1997). 'Differences Between Entrepreneurs and Managers in Large Organizations: Biases and Heuristics in Strategic Decisionmaking'. Journal of Business Venturing, 12: 9-30.

Collins, O. F., and D. G. Moore (1964). The Enterprising Man. East Lansing: Bureau of Business and Economic Research, Graduate School of Business Administration, Michigan State University.

Defoort, C. (2006). 'Tendances de Long Terme des Migrations Internationales. Analyse à Partir des 6 Principaux Pays Receveurs'. Working Paper, EQUIPPE (Universités de Lille, France) and IRES (Université Catholique de Louvain).

Docquier, F., and A. Bhargava (2007). 'A New Panel Data Set on Physicians' Emigration Rates (1991-2004)’. Working Paper, Catholic University of Louvain (Belgium) and University of Houston (USA). Also see accompanying dataset prepared by the Trade Team - Development Research Group, as part of the International Migration and Development Program (World Bank contract PO. 7669002).

Docquier, F., and E. Lodigiani (2008). 'Skilled Migration and Business Networks'. CREA Discussion Paper Series 08-11, Center for Research in Economic Analysis, University of Luxembourg.

Florida, R. (2005). The Flight of the Creative Class: The New Global Competition for Talent. HarperCollins: New York.

Gaglio, C., and J. Katz (2001). 'The Psychological Basis of Opportunity Identification: Entrepreneurial Alertness’. Journal of Small Business Economics, 16: 95-111. 
Gartner, W. B. (2001). 'Is There an Elephant in Entrepreneurship? Blind Assumptions in Theory Development'. Entrepreneurship Theory and Practice, 25 (4): 27-39.

GEM - Global Entrepreneurship Monitor (2006). ‘GEM 2006 Summary Results', by N. Bosma and R. Harding, GEM Project, Babson College and London Business School.

Grossmann, V., and D. Stadelmann (2008). 'International Mobility of the Highly Skilled, Endogenous R\&D, and Public Infrastructure Investment’. IZA Discussion Paper No. 3366, February.

Heidrick and Struggles and the Economist Intelligence Unit (2007) 'Mapping Global Talent: Essays and Insights'. Available at: http://www.heidrick.com/NR/rdonlyres/0F2C2980-80DB-4F75-8A30D3C6FDDAD6B1/0/Heidrick_GTI_booklet.pdf

ILO (2006). 'Competing for Global Talent'. In C. Kuptsch and Pang Eng Fong (eds), Geneva, Switzerland: International Labour Organization (International Institute for Labour Studies).

Jones, B. J., S. Wuchty, and B. Uzzi (2008). 'Multi-university Research Teams: Shifting Impact, Geography, and Stratification in Science'. Science, 322: 1259-62.

Kirzner, I. (1979). Competition and Entrepreneurship. Chicago and London: University of Chicago Press.

Knight, G. A. (2001). 'Entrepreneurship and Strategy in the International SME'. Journal of International Management, 7 (3): 155-71.

McClelland, D. (1961). The Achieving Society. Princeton, JH: Van Nostrand.

Mosca, G. (1960). The Ruling Class. McGraw-Hill Education: New York.

OECD (2004). Highly Skilled Labour and International Mobility in South America. OECD Publications: Paris.

Pareto, V. ([1968] 1991). The Rise and Fall of Elites: An Application of theoretical sociology. Transaction Publishers: New Brunswick, NJ.

Saxenian, A. (2006a). The New Argonauts: Regional Advantage in a Global Economy. Cambridge, MA: Harvard University Press.

Saxenian, A. (2006b). 'International Mobility of Engineers and the Rise of Entrepreneurship in the Periphery'. UNU-WIDER Research Paper No. 2006/142, November.

Saxenian, A. (2008). 'The International Mobility of Entrepreneurs and Regional Upgrading in India and China'. In A. Solimano (ed.), The International Mobility of Talent. Types, Causes and Development Impact. Oxford University Press, Oxford (UK) and New York (USA).

Shane, S., and S. Venkataraman (2000). 'The Promise of Entrepreneurship as a Field of Research’. Academy of Management Review, 25 (1): 217-26.

Solimano, A. (ed.) (2008). The International Mobility of Talent. Types, Causes, and Development Impact. Oxford University Press: New York. 
Solimano, A. (2010) International Migration in the Age of Globalization. Cambridge University Press, forthcoming.

Spilimbergo, A. (2007). 'Democracy and Foreign Education'. IMF Working Paper WP/07/51, March.

WDI (2007). The World Bank’s World Development Indicators. Online database.

Vincent-Lancrin, S. (2008). 'Student Mobility'. In OECD (ed.), World Migration Report 2008, Ch. 4.

Wright Mills, C. ([1956] 2000). The Power Elite. Oxford University Press: New York.

Wuchty, S., B. J. Jones, and B. Uzzi (2007). 'The Increasing Dominance of Teams in the Production of Knowledge'. Science, 316: 1036-39. 
Table 1: Prizes to talent: Nobel Laureates in Science and Economics (1980-2008)

\begin{tabular}{lccccc}
\hline \multicolumn{1}{c}{ Countries } & Physics & Chemistry & Medicine & Economics & $\begin{array}{c}\text { Total (w/o } \\
\text { literature) }\end{array}$ \\
\hline USA & 32 & 27 & 31 & 27 & 117 \\
USA (immigrants) & 9 & 11 & 8 & 7 & 35 \\
United Kingdom & 0 & 4 & 8 & 4 & 16 \\
United Kingdom (immigrants) & 0 & 1 & 2 & 1 & 4 \\
Germany & 6 & 4 & 5 & 1 & 16 \\
Germany (immigrants) & 4 & 0 & 0 & 0 & 4 \\
France & 2 & 2 & 3 & 1 & 8 \\
Japan & 3 & 4 & 1 & 0 & 8 \\
Sweden & 1 & 0 & 4 & 0 & 5 \\
Switzerland & 2 & 2 & 1 & 0 & 5 \\
Canada & 2 & 1 & 0 & 1 & 4 \\
The Netherlands & 3 & 1 & 0 & 0 & 4 \\
Other Countries & 5 & 4 & 4 & 3 & 16 \\
\hline
\end{tabular}

Source: Updated from Solimano (2009) based on data available at http://nobelprize.org.

Table 2: Prizes to talent: Nobel Prizes in Literature (1980-2008)

\begin{tabular}{|c|c|c|c|}
\hline Countries & $\begin{array}{l}\text { Number } \\
\text { of prizes }\end{array}$ & Countries & $\begin{array}{l}\text { Number } \\
\text { of prizes }\end{array}$ \\
\hline United Kingdom (immigrants) & 3 & Ireland & 1 \\
\hline United Kingdom & 2 & Italy & 1 \\
\hline South Africa & 2 & Japan & 1 \\
\hline Austria & 1 & Mexico & 1 \\
\hline Colombia & 1 & Nigeria & 1 \\
\hline Czechoslovakia & 1 & Poland & 1 \\
\hline Egypt & 1 & Poland \& USA & 1 \\
\hline Hungary & 1 & Portugal & 1 \\
\hline France & 2 & Saint Lucia & 1 \\
\hline France (immigrant) & 1 & Turkey & 1 \\
\hline Germany & 1 & USA & 1 \\
\hline Spain & 1 & USA (immigrants) & 1 \\
\hline
\end{tabular}

Source: Solimano (2010) based on data available at http://nobelprize.org. 
Table 3: Distribution of talented elites: global creativity Index, 2005

\begin{tabular}{clcccc}
\hline Rank & \multicolumn{1}{c}{ Country } & $\begin{array}{c}\text { Global } \\
\text { creativity } \\
\text { index }\end{array}$ & Talent index & $\begin{array}{c}\text { Technology } \\
\text { index }\end{array}$ & $\begin{array}{c}\text { Tolerance } \\
\text { index }\end{array}$ \\
\hline Top 10 Countries & & & & \\
\hline 1 & Sweden & 0.808 & 0.642 & 0.819 & 0.964 \\
2 & Japan & 0.766 & 0.702 & 0.785 & 0.811 \\
3 & Finland & 0.684 & 0.728 & 0.626 & 0.698 \\
4 & United States & 0.666 & 0.601 & 0.827 & 0.571 \\
5 & Switzerland & 0.637 & 0.541 & 0.625 & 0.744 \\
6 & Denmark & 0.613 & 0.597 & 0.385 & 0.858 \\
7 & Iceland & 0.612 & 0.658 & 0.463 & 0.717 \\
8 & The Netherlands & 0.611 & 0.643 & 0.366 & 0.824 \\
9 & Norway & 0.595 & 0.686 & 0.279 & 0.819 \\
10 & Germany & 0.577 & 0.468 & 0.511 & 0.753 \\
\hline & & & & \\
Developing and Transition Economies & & & & \\
25 & Russian Federation & 0.339 & 0.521 & 0.112 & 0.385 \\
27 & Ukraine & 0.296 & 0.404 & 0.103 & 0.38 \\
33 & Uruguay & 0.24 & 0.22 & 0.021 & 0.478 \\
36 & China & 0.23 & 0.031 & 0.109 & 0.55 \\
38 & Argentina & 0.199 & 0.193 & 0.045 & 0.357 \\
40 & Chile & 0.185 & 0.16 & 0.055 & 0.339 \\
41 & India & 0.177 & 0.085 & 0.137 & 0.309 \\
42 & Mexico & 0.164 & 0.15 & 0.043 & 0.299 \\
43 & Brazil & 0.159 & 0.128 & 0.083 & 0.266 \\
45 & Romania & 0.127 & 0.131 & 0.035 & 0.214 \\
\hline
\end{tabular}

Source: Florida (2005). 
Table 4: Distribution of talented elites: global talent Index, 2007

\begin{tabular}{clc}
\hline Rank & \multicolumn{1}{c}{ Country } & $\begin{array}{c}\text { Global talent } \\
\text { index } \\
\text { (score) }\end{array}$ \\
\hline Top 10 Countries & \\
\hline 1 & United States & 52 \\
2 & Canada & 47 \\
3 & The Netherlands & 46 \\
4 & United Kingdom & 46 \\
5 & Sweden & 45 \\
6 & Germany & 43 \\
7 & Australia & 43 \\
8 & China & 42 \\
9 & France & 41 \\
10 & India & 39 \\
\hline & and Transition Economies & \\
Developing and & 42 \\
8 & China & 39 \\
10 & India & 34 \\
17 & Argentina & 33 \\
18 & Russia & 33 \\
19 & Ukraine & 31 \\
21 & Mexico & 30 \\
23 & Brazil & 29 \\
24 & South Africa & 29 \\
25 & Egypt & 25 \\
27 & Nigeria & \\
\hline & &
\end{tabular}

Source: Heidrick and Struggles and the Economist Intelligence Unit (2007). 
Table 5: Scientific and technical production: journal articles, researchers and technicians (average 1998-2003)

\begin{tabular}{|c|c|c|c|}
\hline Country & $\begin{array}{c}\text { Scientific and } \\
\text { technical journal } \\
\text { articles }\end{array}$ & $\begin{array}{l}\text { Researchers in R\&D } \\
\text { (per mill. people) }\end{array}$ & $\begin{array}{l}\text { Technicians in R\&D } \\
\text { (per mill. people) }\end{array}$ \\
\hline \multicolumn{4}{|l|}{ Top Ten Countries } \\
\hline United States & 200,088 & 4,556 & -- \\
\hline Japan & 56,463 & 5,188 & 595 \\
\hline United Kingdom & 47,931 & 2,706 & -- \\
\hline Germany & 43,456 & 3,134 & 1,372 \\
\hline France & 31,347 & 2,930 & -- \\
\hline Canada & 23,178 & 3,451 & 709 \\
\hline Italy & 21,917 & 1,168 & 1,347 \\
\hline China & 20,320 & 537 & -- \\
\hline Russian Federation & 16,785 & 3,400 & 565 \\
\hline Spain & 15,281 & 1,841 & 663 \\
\hline \multicolumn{4}{|l|}{ Other Selected Countries } \\
\hline India & 11,015 & 119 & 102 \\
\hline Korea, Rep. & 10,229 & 2,594 & 510 \\
\hline Brazil & 6,814 & 344 & 332 \\
\hline Finland & 4,915 & 6,915 & 3,297 \\
\hline Mexico & 3,126 & 240 & 97 \\
\hline New Zealand & 2,947 & 3,222 & 744 \\
\hline Argentina & 2,870 & 706 & 308 \\
\hline Singapore & 2,387 & 3,920 & 359 \\
\hline South Africa & 2,332 & 307 & 73 \\
\hline Chile & 1,185 & 419 & 298 \\
\hline \multicolumn{4}{|l|}{ By Region } \\
\hline European Monetary Union & 146,841 & 2,461 & 1,224 \\
\hline Europe \& Central Asia & 40,022 & 2,027 & 385 \\
\hline East Asia \& Pacific & 22,041 & 490 & -- \\
\hline Latin America \& Caribbean & 15,491 & -- & -- \\
\hline South Asia & 11,600 & 119 & 102 \\
\hline Middle East \& North Africa & 4,048 & -- & -- \\
\hline Sub-Saharan Africa & 3,770 & -- & -- \\
\hline World & 645,188 & -- & -- \\
\hline \multicolumn{4}{|l|}{ By Income } \\
\hline High income & 548,216 & 3,667 & -- \\
\hline High income: OECD & 529,218 & 3,695 & -- \\
\hline High income: nonOECD & 18,999 & -- & -- \\
\hline Low \& middle income & 96,972 & -- & -- \\
\hline Middle income & 83,802 & 714 & -- \\
\hline Upper middle income & 46,057 & 1,360 & 318 \\
\hline Lower middle income & 37,745 & 490 & -- \\
\hline Low income & 13,170 & -- & -- \\
\hline
\end{tabular}

Source: Own elaboration based on information from the World Bank's WDI (2007). 
Table 6: Destinations of foreign students studying in OECD countries by origin (2004)

\begin{tabular}{lcccc}
\cline { 2 - 4 } & \multicolumn{4}{c}{ Destination } \\
\cline { 2 - 5 } & North America & Europe & Asia-Pacific & OECD \\
\hline Africa & $20 \%$ & $77 \%$ & $3 \%$ & $100 \%$ \\
North America & $44 \%$ & $43 \%$ & $13 \%$ & $100 \%$ \\
South America & $56 \%$ & $41 \%$ & $2 \%$ & $100 \%$ \\
○े & Asia & $32 \%$ & $28 \%$ & $100 \%$ \\
Europe & $40 \%$ & $81 \%$ & $3 \%$ & $100 \%$ \\
Oceania & $16 \%$ & $19 \%$ & $54 \%$ & $100 \%$ \\
World & $27 \%$ & $52 \%$ & $17 \%$ & $100 \%$ \\
\hline
\end{tabular}

Source: Vincent-Lancrin (2008), Table 4.1.

Table 7: Applied talent: patent applications (average 1998-2004).

\begin{tabular}{|c|c|c|c|c|c|c|c|c|}
\hline \multirow[b]{2}{*}{ Country / Country Group } & \multicolumn{2}{|c|}{ Patent Applications, Total } & \multicolumn{3}{|c|}{ Patent Applications, Nonresidents } & \multicolumn{3}{|c|}{ Patent Applications, Residents } \\
\hline & $\begin{array}{c}\text { Number of } \\
\text { Patents }\end{array}$ & $\begin{array}{c}\% \text { of } \\
\text { Worldwide } \\
\text { Patents } \\
\end{array}$ & $\begin{array}{c}\text { Number of } \\
\text { Patents }\end{array}$ & $\begin{array}{c}\% \text { of Total } \\
\text { Country } \\
\text { Patents }\end{array}$ & $\begin{array}{c}\% \text { of } \\
\text { Worldwide } \\
\text { Patents } \\
\end{array}$ & $\begin{array}{c}\text { Number of } \\
\text { Patents }\end{array}$ & $\begin{array}{c}\% \text { of Total } \\
\text { Country } \\
\text { Patents }\end{array}$ & $\begin{array}{c}\% \text { of } \\
\text { Worldwide } \\
\text { Patents }\end{array}$ \\
\hline \multicolumn{9}{|l|}{ Top Ten Countries } \\
\hline Japan & 417,760 & 32.61 & 50,952 & 12.20 & 3.98 & 366,808 & 87.80 & 28.64 \\
\hline United States & 308,420 & 24.08 & 141,917 & 46.01 & 11.08 & 166,503 & 53.99 & 13.00 \\
\hline Korea, Rep. & 116,711 & 9.11 & 41,708 & 35.74 & 3.26 & 75,003 & 64.26 & 5.86 \\
\hline China & 87,052 & 6.80 & 51,786 & 59.49 & 4.04 & 35,267 & 40.51 & 2.75 \\
\hline Germany & 59,484 & 4.64 & 10,897 & 18.32 & 0.85 & 48,587 & 81.68 & 3.79 \\
\hline Canada & 37,921 & 2.96 & 33,937 & 89.49 & 2.65 & 3,985 & 10.51 & 0.31 \\
\hline United Kingdom & 31,326 & 2.45 & 10,897 & 34.79 & 0.85 & 20,429 & 65.21 & 1.59 \\
\hline Russian Federation & 31,056 & 2.42 & 8,751 & 28.18 & 0.68 & 22,305 & 71.82 & 1.74 \\
\hline Australia & 28,582 & 2.23 & 20,401 & 71.38 & 1.59 & 8,182 & 28.62 & 0.64 \\
\hline France & 17,025 & 1.33 & 3,386 & 19.89 & 0.26 & 13,639 & 80.11 & 1.06 \\
\hline \multicolumn{9}{|l|}{ Other Selected Countries } \\
\hline Brazil & 17,010 & 1.33 & 13,813 & 81.20 & 1.08 & 3,197 & 18.80 & 0.25 \\
\hline India & 10,597 & 0.83 & 6,434 & 60.71 & 0.50 & 4,163 & 39.29 & 0.32 \\
\hline Mexico & 10,318 & 0.81 & 9,841 & 95.38 & 0.77 & 477 & 4.62 & 0.04 \\
\hline Israel & 9,266 & 0.72 & 7,701 & 83.11 & 0.60 & 1,565 & 16.89 & 0.12 \\
\hline Singapore & 8,699 & 0.68 & 8,217 & 94.47 & 0.64 & 481 & 5.53 & 0.04 \\
\hline Argentina & 5,602 & 0.44 & 4,772 & 85.19 & 0.37 & 830 & 14.81 & 0.06 \\
\hline Indonesia & 3,682 & 0.29 & 3,466 & 94.14 & 0.27 & 216 & 5.86 & 0.02 \\
\hline Chile & 2,966 & 0.23 & 2,744 & 92.50 & 0.21 & 223 & 7.50 & 0.02 \\
\hline Netherlands & 2,844 & 0.22 & 534 & 18.77 & 0.04 & 2,310 & 81.23 & 0.18 \\
\hline Finland & 2,554 & 0.20 & 260 & 10.20 & 0.02 & 2,293 & 89.80 & 0.18 \\
\hline \multicolumn{9}{|l|}{ By Income } \\
\hline High income & $1,075,408$ & 83.95 & 348,972 & 32.45 & 27.24 & 726,436 & 67.55 & 56.71 \\
\hline High income: OECD & $1,048,070$ & 81.82 & 323,886 & 30.90 & 25.28 & 724,184 & 69.10 & 56.53 \\
\hline High income: nonOECD & 27,339 & 2.13 & 25,086 & 91.76 & 1.96 & 2,252 & 8.24 & 0.18 \\
\hline Low \& middle income & 205,543 & 16.05 & 121,514 & 59.12 & 9.49 & 84,028 & 40.88 & 6.56 \\
\hline Middle income & 193,221 & 15.08 & 114,328 & 59.17 & 8.93 & 78,893 & 40.83 & 6.16 \\
\hline Upper middle income & 67,258 & 5.25 & 38,274 & 56.91 & 2.99 & 28,984 & 43.09 & 2.26 \\
\hline Lower middle income & 125,963 & 9.83 & 76,054 & 60.38 & 5.94 & 49,909 & 39.62 & 3.90 \\
\hline Low income & 12,322 & 0.96 & 7,187 & 58.32 & 0.56 & 5,135 & 41.68 & 0.40 \\
\hline World & $1,280,951$ & 100.00 & 470,487 & 36.73 & 36.73 & 810,464 & 63.27 & 63.27 \\
\hline
\end{tabular}

Source: Own elaboration based on information from the World Bank's WDI (2007). 
Table 8: Intra-company transferees from South America to the United States (1996-2002)

\begin{tabular}{lrrrr}
\hline Country & 1996 & 1998 & 2000 & \multicolumn{1}{c}{2002} \\
\hline Argentina & 1,524 & 2,580 & 3,764 & 6,628 \\
Bolivia & 42 & 69 & 88 & 173 \\
Brazil & 4,175 & 5,831 & 8,470 & 9,562 \\
Chile & 590 & 1,131 & 1,562 & 2,096 \\
Colombia & 1,128 & 1,929 & 4,729 & 7,692 \\
Ecuador & 211 & 255 & 496 & 886 \\
Guyana & 17 & 25 & 50 & 82 \\
Paraguay & 34 & 64 & 90 & 59 \\
Peru & 393 & 496 & 929 & 1,392 \\
Uruguay & 139 & 160 & 318 & 537 \\
Venezuela (RB) & 2,179 & 2,775 & 4,495 & 7,963 \\
\hline South America & 12,428 & 17,313 & 26,991 & 39,072 \\
\hline As \% of Total & $7.4 \%$ & $7.5 \%$ & $8.5 \%$ & $11.8 \%$ \\
\hline
\end{tabular}

Source: OECD (2004).

Table 9: Government Expenditure in Research \& Development (average 1998-2004)

\begin{tabular}{|c|c|c|c|}
\hline Country & $\begin{array}{c}\text { Average as } \\
\% \text { of GDP } \\
(1998-2004)\end{array}$ & Country Group & $\begin{array}{c}\text { Average as } \\
\% \text { of GDP } \\
(1998-2004)\end{array}$ \\
\hline Top Ten Investors in R\&D & & World & 2.17 \\
\hline Israel & 4.42 & & \\
\hline Sweden & 3.85 & By Region & \\
\hline Finland & 3.34 & European Monetary Union & 1.90 \\
\hline Japan & 3.04 & East Asia \& Pacific & 0.99 \\
\hline Iceland & 2.76 & Europe \& Central Asia & 0.83 \\
\hline United States & 2.68 & South Asia & 0.70 \\
\hline Switzerland & 2.57 & Latin America \& Caribbean & 0.57 \\
\hline Germany & 2.48 & Middle East \& North Africa & $N / A$ \\
\hline Korea, Rep. & 2.46 & Sub-Saharan Africa & $\mathrm{N} / \mathrm{A}$ \\
\hline Denmark & 2.35 & \multirow{2}{*}{\multicolumn{2}{|c|}{ By Income }} \\
\hline & & & \\
\hline Other Selected Countries & & High income & 2.42 \\
\hline France & 2.20 & High income: OECD & 2.43 \\
\hline United Kingdom & 1.87 & High income: nonOECD & N/A \\
\hline Russian Federation & 1.12 & & \\
\hline China & 1.08 & Low \& middle income & 0.70 \\
\hline Brazil & 0.97 & & \\
\hline India & 0.79 & Middle income & 0.74 \\
\hline South Africa & 0.76 & Upper middle income & 0.68 \\
\hline Chile & 0.57 & Lower middle income & 0.77 \\
\hline Argentina & 0.42 & & \\
\hline Mexico & 0.39 & Low income & 0.70 \\
\hline
\end{tabular}

Source: Own elaboration based on information from the World Bank's WDI (2007). 
Table 10: Composite entrepreneurship indicator: attractiveness of countries to develop entrepreneurial activities

Period 1998-2001

\begin{tabular}{lr}
\hline \multicolumn{1}{c}{ Importance of dimensions } & \multicolumn{1}{c}{$\%$} \\
\hline 1. Entrepreneurial Activity & 10.27 \\
\hline 2. Employment & 13.29 \\
3. Economic Activity & 9.00 \\
4. Entrepreneurship Spirit, & 4.81 \\
Culture, and Iniciative & \\
5. Barriers to Entrepreneurial & 15.74 \\
Activity and Business & \\
6. Knowledge Procurement & 13.28 \\
7. Innovation & 33.61 \\
Total & 100.00 \\
\hline \multicolumn{2}{c}{ Country } \\
\hline Ranking
\end{tabular}

Top ten countries

\begin{tabular}{clc}
1 & United States & 1.1863 \\
2 & Switzerland & 0.7991 \\
3 & Japan & 0.7424 \\
4 & Sweden & 0.7317 \\
5 & China & 0.6296 \\
6 & Finland & 0.5787 \\
7 & Germany & 0.4533 \\
8 & Australia & 0.3864 \\
9 & Korea, Rep. & 0.3720 \\
10 & Canada & 0.3370 \\
\hline & & \\
Other selected countries & \\
19 & Brazil & 0.0477 \\
21 & New Zealand & 0.0144 \\
24 & Argentina & -0.0062 \\
26 & Chile & -0.0157 \\
27 & Israel & -0.0182 \\
28 & India & -0.0232 \\
29 & Mexico & -0.0246 \\
34 & Singapore & -0.0543 \\
44 & Indonesia & -0.1170 \\
49 & Russian Federation & -0.1317 \\
\hline
\end{tabular}

Period 2002-2005

\begin{tabular}{lr}
\hline \multicolumn{1}{c}{ Importance of dimensions } & $\%$ \\
\hline 1. Entrepreneurial Activity & 6.01 \\
2. Employment & 22.01 \\
3. Economic Activity & 13.21 \\
4. Entrepreneurship Spirit, & 12.42 \\
Culture, and Initiative & \\
5. Barriers to Entrepreneurial & 3.05
\end{tabular}

Activity and Business

6. Knowledge Procurement $\quad 15.86$

7. Innovation 27.44

Total 100.00

\begin{tabular}{clc}
\hline Ranking & \multicolumn{1}{c}{ Country } & Index \\
\hline & & \\
Top ten & & \\
\hline 1 & China & \\
2 & United States & 1.1502 \\
3 & Indonesia & 1.1075 \\
4 & Korea, Rep. & 1.0372 \\
5 & Japan & 0.4491 \\
6 & Finland & 0.2922 \\
7 & Brazil & 0.2584 \\
8 & Mexico & 0.2314 \\
9 & Switzerland & 0.1970 \\
10 & Israel & 0.1790 \\
\end{tabular}

\begin{tabular}{cll} 
Other selected countries & \\
\hline 11 & Canada & 0.1473 \\
12 & Argentina & 0.1380 \\
13 & Australia & 0.1099 \\
17 & Sweden & 0.0700 \\
19 & Russian Federation & 0.0643 \\
20 & India & 0.0226 \\
21 & New Zealand & 0.0194 \\
56 & Singapore & -0.1744 \\
61 & Germany & -0.2329 \\
64 & Chile & -0.2423 \\
\hline
\end{tabular}

Source: Avanzini (2009). See its Appendix for details. 
Figure 1: Entrepreneurship and GDP: the 'U-shaped' relationship for 42 selected countries (2005-2006)

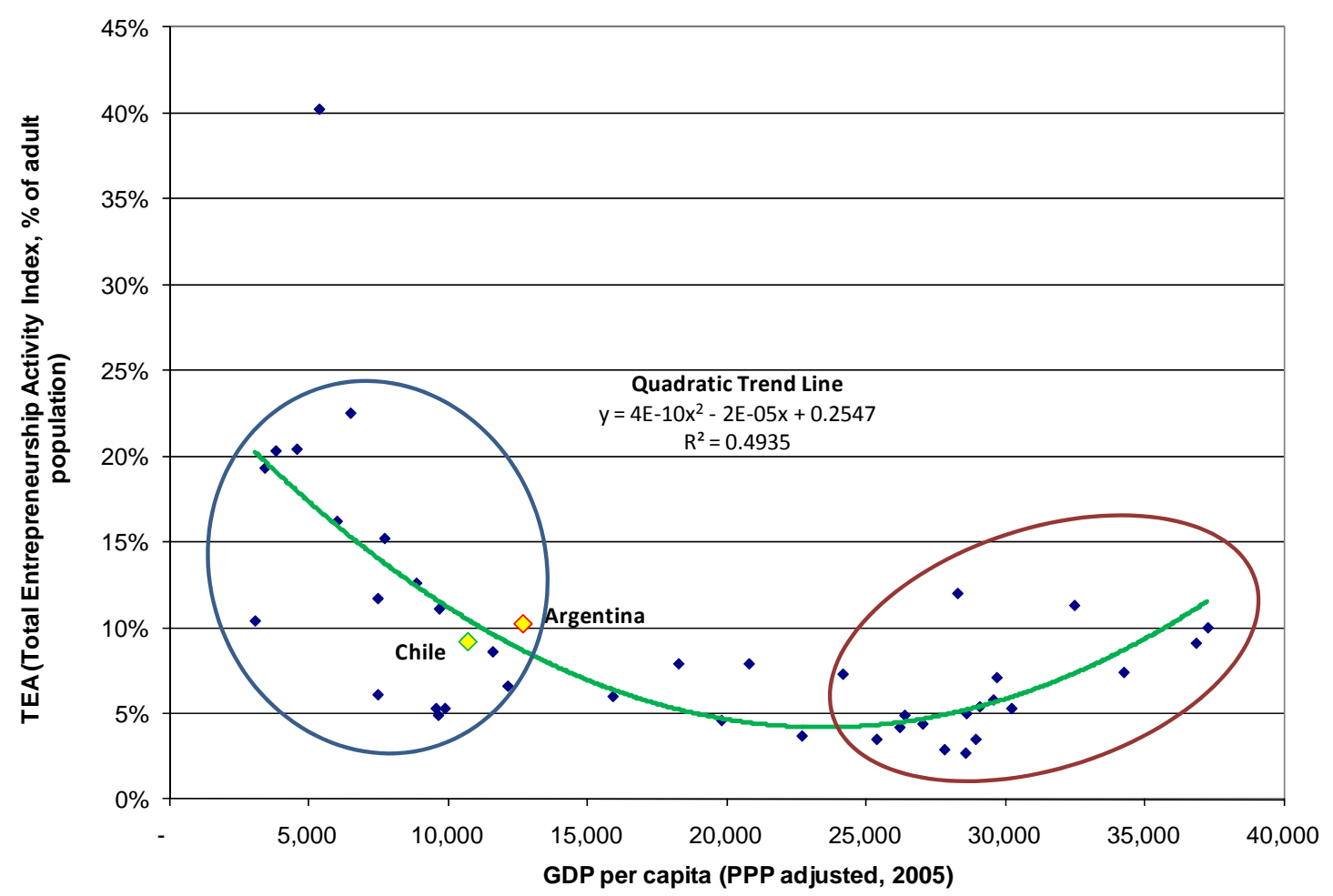

Source: Avanzini (2007), Figure 1, based on information from GEM (2006) and World Bank's WDI (2007). 
Figure 2: High-skilled migration rates for six selected OECD countries (1975-2000)

Panel A: Immigration

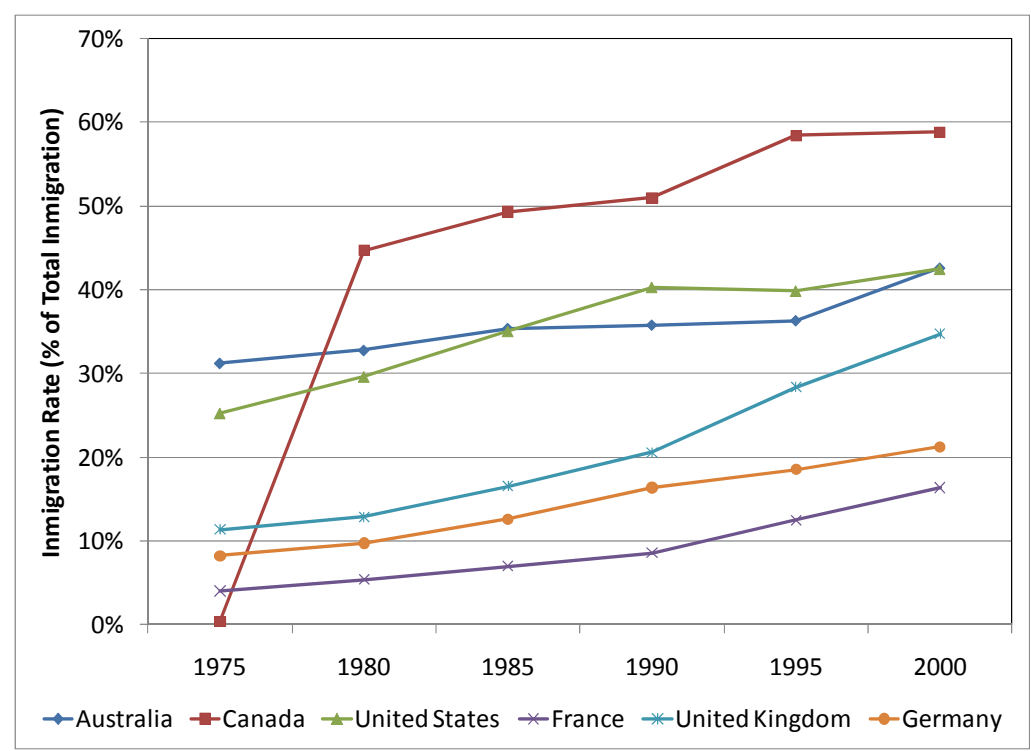

Panel B: Emigration

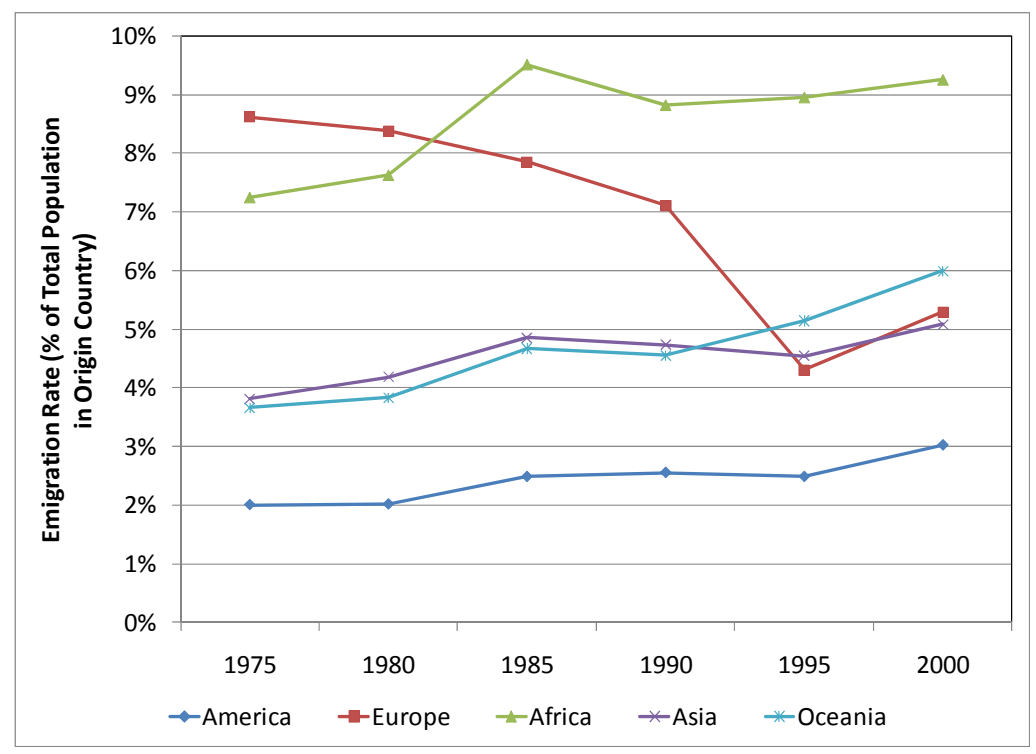

Source: Defoort (2006), Tables 2 and 3 (country list available in its Annex).

Note: The High-Skilled Immigration Rate corresponds to the proportion of High-Skilled Immigration Stock in Total Immigration for each country. The High-Skilled Emigration Rate is defined as the ratio of the number of high-skilled emigrants aged 25+ to the six major receiving countries in Panel A to the total number of skilled natives aged 25+ (residents + emigrants). High-Skilled workers are those with a post-secondary certificate. Data for 1975 required many interpolations and is less reliable. 
Figure 3: Medical talent emigration rate per region, 1991-2004

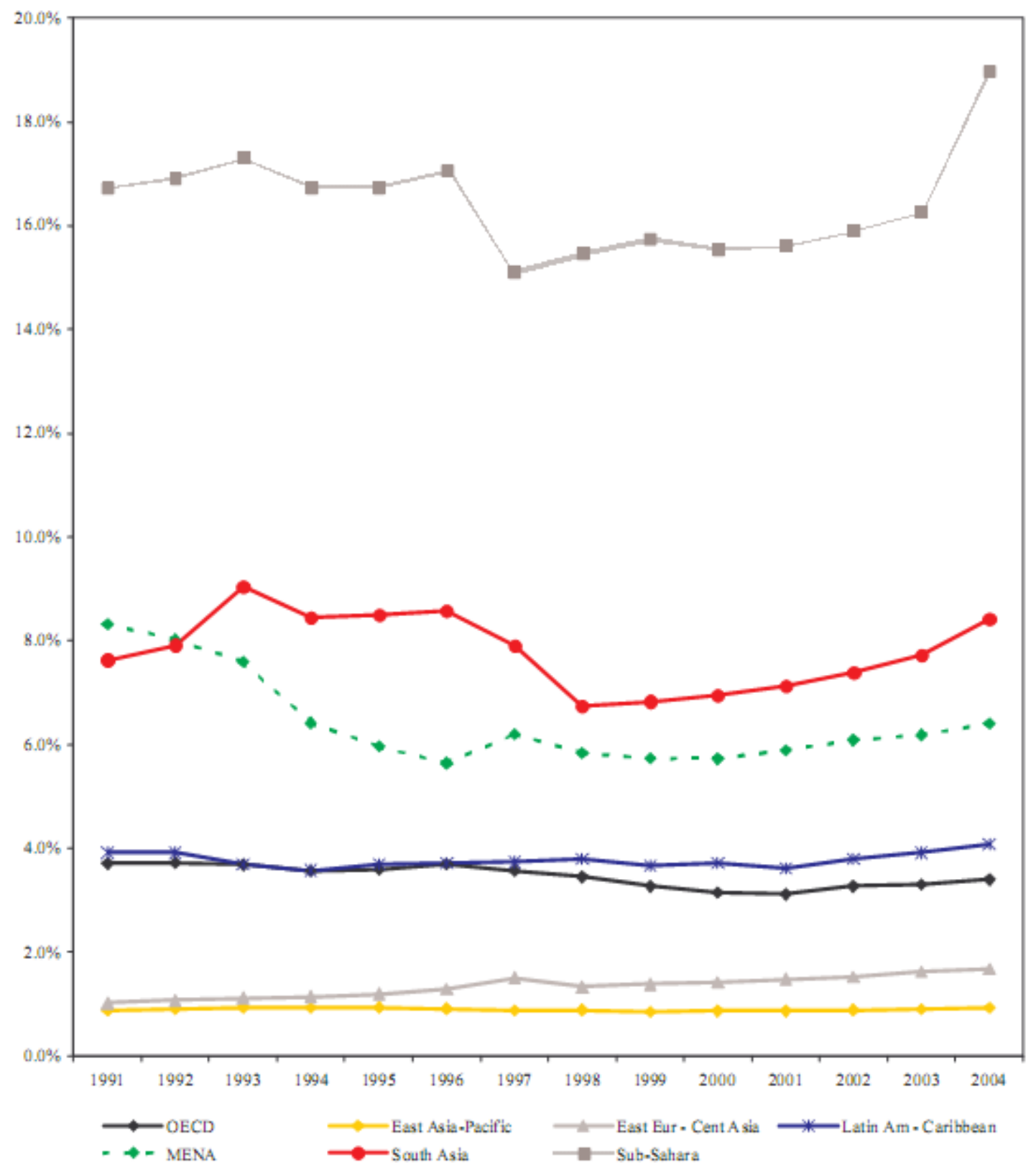

Source: Docquier and Bhargava (2007), Figure 1 and accompanying dataset.

Note: MENA stands for Middle-East and Northern African Countries. Countries included in each group are described in the same paper. 